\title{
Experimental poisoning by Niedenzuella stannea in cattle and corresponding detection of monofluoroacetate
}

\author{
Felipe Peixoto de Arruda $^{1 *}$ Flávio Henrique Bravim Caldeira $^{2}$ Kássia Renostro Ducatti $^{1}$ \\ Kalinne Stephanie Bezerra ${ }^{1}$ Clairton Marcolongo-Pereira ${ }^{3}$ Stephen Tomas Lee $^{4}$ Daniel Cook $^{4}$ \\ Franklin Riet-Correa ${ }^{5}$ Edson Moleta Colodel ${ }^{6}$
}

\footnotetext{
'Programa de Pós-graduação em Ciências Veterinárias (PPGVET), Faculdade de Medicina Veterinaria (FAVET), Universidade Federal de Mato Grosso (UFMT). Campus Universitário Cuiabá, Av. Fernando Corrêa da Costa, 2367, Bairro Boa Esperança, 78069-900, Cuiabá, MT, Brasil. E-mail: felipe fp@hotmail.com. "Corresponding author

${ }^{2}$ Instituto Federal de Educação, Ciência e Tecnologia de Rondônia (IFRO), Colorado do Oeste, RO, Brasil.

${ }^{3}$ Centro Universitário Ritter dos Reis (UniRitter). Porto Alegre, RS, Brasil.

${ }^{4}$ Poisonous Plant Research Laboratory, Agricultural Research Service, U.S. Department of Agriculture, Logan, UT, United States.

${ }^{5}$ National Institute for Agriculture Research (INIA), La Estanzuela, Colonia, Uruguay.

${ }^{6}$ Faculdade de Medicina Veterinária (FAVET). Universidade Federal de Mato Grosso (UFMT). Campus Universitário Cuiabá, Cuiabá, MT, Brasil.
}

ABSTRACT: In Brazil sodium monofluoroacetate (MFA) containing plants are represented by 16 species that belong to three principle genera Palicourea (Rubiaceae), Amorimia (Malpighiaceae), and Tanaecium (Bignoniaceae). These plants can cause acute cardiac failure often referred to as sudden death syndrome. The objective of this paper was to determine if $\mathbf{N}$. stannea contains MFA and to report the clinical signs and pathology of cattle experimentally poisoned by this plant. MFA was detected in all $\mathbf{N}$. stannea plant parts except mature leaves. Niedenzuella stannea was dosed to cattle at single doses of $15-30 \mathrm{~g} \mathrm{~kg}^{-1} \mathrm{bw}$. Clinical signs and pathology observed were similar to those reported by other MFA-containing plants. Animals showed marked tachycardia, labored breathing, muscle tremors, loss of balance, ataxia, falling, recumbence, pedaling movements, and opisthotonous leading to death in few minutes. Gross lesions included engorgement of the large veins, severe lung edema, and petechiae, ecchymosis and suffusions in the pericardium, epicardium and pleura. Histologically, hydropic vacuolar degeneration and necrosis of epithelial cells of the kidney were observed. Cattle that received daily doses of $4 \mathrm{~g} \mathrm{~kg}^{-1}$ body weight for 24 days showed no clinical signs. In summary, this is the first report that $\mathrm{N}$. stannea contains monofluoroacetate and causes sudden death in cattle.

Key words: monofluoracetate, toxic plants, Niedenzuella stannea, sudden death syndrome, acute cardiac failure.

Intoxicação experimental por Niedenzuella stannea em

bovinos e correspondente detecção de monofluoroacetato

RESUMO: No Brasil as plantas que contêm monofluoroacetato de sódio (MFA) são representadas por 16 espécies e pertencem a três principais gêneros: Palicourea (Rubiaceae), Amorimia (Malpighiaceae) e Tanaecium (Bignoniaceae). Estas plantas podem causar falha cardíaca aguda que frequentemente é referida como sindrome da morte súbita. O objetivo deste trabalho é determinar se $\mathbf{N}$. stannea contêm MFA e relatar os sinais clínicos e patológicos em bovinos associados à intoxicação experimental por esta planta. Monofluoroacetato foi detectado em todas as partes da N. stannea, exceto em folhas maduras. Niedenzuella stannea foi fornecida a bovinos em doses únicas de 15-30 $\mathrm{kg}^{-1}$ peso vivo. Os sinais clínicos e patológicos observados foram similares aos relatados pelas intoxicações por outras plantas que contêm monofluoroacetato. Os animais apresentaram taquicardia acentuada, respiração profunda, tremores musculares, perda de equilibrio, ataxia, queda, decúbito, movimentos de pedalagem e opistótono, seguido de morte em poucos minutos. As lesões macroscópicas observadas foram ingurgitamento de grandes vasos, edema pulmonar acentuado, petéquias, equimoses e sufusões no pericárdio, epicárdio e pleura. Histologicamente foi observado degeneração hidrópica vacuolar e necrose de células do epitélio renal. Bovinos que receberam doses diárias de $4 \mathrm{~g} \mathrm{~kg}^{-1}$ peso vivo por 24 dias seguidos não apresentaram sinais clínicos. Este é o primeiro relato que $\mathbf{N}$. stannea contêm MFA e causa morte súbita em bovinos.

Palavras-chave: monofluoroacetato, plantas tóxicas, Niedenzuella stannea, morte súbita, falha cardíaca aguda.

\section{INTRODUCTION}

Many plant species contain the compound monofluoroacetate (MFA) (LEE et al., 2014). MFA is a toxic principle that inhibits the TCA cycle subsequently disrupting energy production in the cell resulting in a dysfunction of metabolic active cells, especially myocardium, certain neurons, and renal tubular epithelium (CLARKE, 1991). In cattle, the primary effects occur in the heart where myocardial damage is exacerbated by exercise as energy requirements are taxed and then exhausted
(TOKARNIA et al., 2012). Death by acute cardiac insufficiency generally occurs when the animals are forced to exercise and is known as sudden death syndrome (TOKARNIA et al., 2012). Sudden death caused by MFA-containing plants in cattle is characterized by tachycardia, labored breathing, loss of balance, ataxia, muscular tremors, falling, recumbence, pedaling movements, and opisthotonus leading to death (TOKARNIA \& DÖBEREINER 1986; GAVA et al., 1998; TOKARNIA et al., 2004).

Different plant genera contain MFA, including some Gastrolobium spp. (Fabaceae) 
in Australia and some Dichapetalum spp. (Dichapetalaceae) in South Africa, which are important causes of sudden death of cattle in those countries (LEE et al., 2014). In Brazil MFA-containing plants are represented by 16 species that belong to three principle genera: Palicourea (Rubiaceae), Amorimia (Malpighiaceae), and Tanaecium (Bignoniaceae) (LEE et al., 2012; DUARTE et al., 2013; CARVALHO et al., 2016). It is estimated that this group of plants cause one-half-million cattle deaths per year, which represents $50 \%$ of all deaths caused by toxic plants in Brazil (TOKARNIA et al., 2012).

In 2013 a survey on farms close to the Araguaia river and its tributaries in the eastern region of the state of Mato Grosso showed that sudden deaths in cattle were associated with the ingestion of Niedenzuella stannea. Outbreaks occurred from May to October, mainly during the dry season between June and August when the plant was sprouting. Toxicity of the plant was demonstrated in sheep by the administration of young leaves to sheep (CALDEIRA et al., in press). Niedenzuella stannea belongs to the Malpighiaceae family and is found in Brazil, Costa Rica, Panama, Bolivia, and Paraguay (ANDERSON, 2006). In Brazil, N. stannea occurs in the Amazonic and Pantanal biomes, in the states of Acre, Amazonas, Amapá, Mato Grosso, Mato Grosso do Sul, Pará, Rondônia and Tocantins (MAMEDE, 2015). Experimental evidence is lacking that demonstrates unequivocally that $\boldsymbol{N}$. stannea causes sudden death in cattle and contains the toxic principle MFA. As a result, the objectives of this research were to report the clinical signs and pathology associated with the experimental poisoning in cattle by $\boldsymbol{N}$. stannea collected from farms with a history of sudden death in cattle and to determine if $\boldsymbol{N}$. stannea contains MFA.

\section{MATERIALS AND METHODS}

\section{Plant collection, analysis, and preparation}

Niedenzuella stannea (Grisebach) W.

R. Anderson (Figure 1) was collected in June 2012 and January 2014 for taxonomic identification and MFA determination. A voucher specimen (accession \#1514056, MICH) was collected, pressed and dried, and sent to Professor William R. Anderson of the University of Michigan Herbarium, Ann Arbor, Michigan, United States for taxonomic identification. Additionally, plant material of $N$. stannea representing different plant parts was collected and sent to the USDA Poisonous Plant Research Laboratory, Logan, UT, USA for MFA determination using a HPLCAPCI-MS method developed by LEE et al. (2012).
Sprouting leaves of $N$. stannea (Figure 1D) were collected in June and July 2014, for experimental poisoning in cattle. All plants were collected along the tributaries of the Araguaia river, at the municipality of Torixoréu, state of Mato Grosso, Brazil (S 16 ${ }^{\circ} 18^{\prime} 58,6^{\prime \prime}$; W 52 $\left.56^{\prime} 02,1^{\prime \prime}\right)$. Leaves of $N$. stannea were weighed and then dried at a controlled temperature of $14^{\circ} \mathrm{C}$ for 24 hours and then in an oven at $55^{\circ} \mathrm{C}$ for an additional $24 \mathrm{~h}$. After drying, the plant was ground and administered to the experimental animals by oral gavage in approximately $15 \mathrm{~L}$ of water.

\section{Cattle dosing with N. stannea}

Eight (6 male, 2 female) 1-3 year-old cattle were dewormed, maintained in paddocks of Brachiaria spp. with water ad libitum, and dosed with young leaves of $N$. stannea. The doses were calculated based on a previous experiment with sheep (CALDEIRA et al., in press). Single doses of $\boldsymbol{N}$. stannea, were administered to two animals at $15 \mathrm{~g} \mathrm{~kg}^{-1}$ body weight $\left(\mathrm{g} \mathrm{kg}^{-1}\right)$, two animals at $20 \mathrm{~g} \mathrm{~kg}^{-1}$ body weight, and one animal at $30 \mathrm{~g}$ $\mathrm{kg}^{-1}$ body weight. Two additional animals were dosed daily at $4 \mathrm{~g} \mathrm{~kg}^{-1}$ for 24 days. One control bovine did not receive the plant but was administered water $(15 \mathrm{~L})$ by oral gavage (Table 1).

Prior to dosing, the cardiac and respiratory rates of the cattle were recorded. At intervals of 2-3 hours after the single bolus dose, the animals were exercised (forced to walk and run) for 10 minutes and examined for alterations in gait as well as cardiac and respiratory frequencies. This evaluation took place regularly except for a $12 \mathrm{~h}$ period corresponding to darkness. Simultaneously, dosed animals were also evaluated for clinical signs at $2-3 \mathrm{~h}$ intervals. In this study mild clinical signs were defined as tachycardia, dyspnea, arrhythmia, apathy, frequent urination, reluctance to move, and engorged jugular while severe clinical signs were defined as falling, recumbence, pedaling movements, opisthotonous, cyanosis, vocalization, and cardiopulmonary arrest.

Cattle that died due to the treatment were necropsied and samples of the brain, lung, heart, spleen, kidneys, omasum, abomasum, small and large intestines, and lymph nodes were fixed in $10 \%$ formalin, embedded in paraffin, cut at $3 \mu \mathrm{m}$, stained by hematoxylin and eosin (HE) (LUNA, 1968), and evaluated by light microscopy.

\section{RESULTS AND DISCUSSION}

Clinical signs observed in experimental studies with MFA-containing plants of the Malpighiaceae family are marked tachycardia, labored 

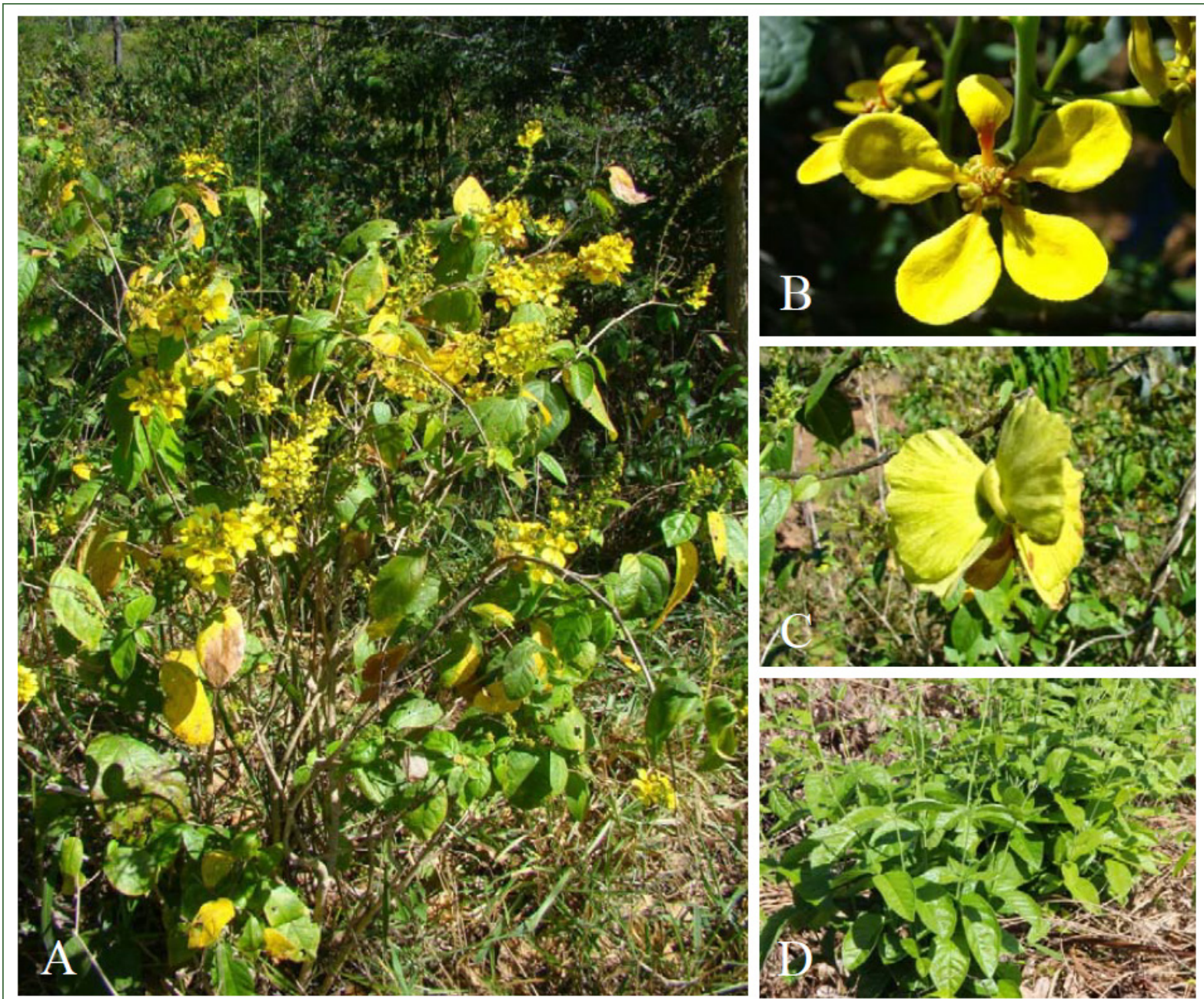

Figure 1 - Niedenzuella stannea, photographed in September 2012 in the municipality of Torixoreu, Mato Grosso, Brazil. A. Flowering shrubs, B. Flower, C. Fruits, D. Sprouting.

breathing, muscle tremors, loss of balance, ataxia, muscular tremors, falling, recumbence, pedaling movements, and opisthotonous leading to death in few minutes. Other animals show less severe clinical signs and survive (TOKARNIA \& DÖBEREINER, 1973; 1986; TOKARNIA et al., 1985; 1994; BECKER et al., 2013). All the cattle that received single doses of $\mathbf{N}$. stannea exhibited similar clinical signs, characteristic of acute cardiac failure, which were more marked and severe in animals that received higher doses and when animals were exercised.

Cattle $(\mathrm{n}=2)$ that were dosed $15 \mathrm{~g} \mathrm{~kg}^{-1}$ showed mild clinical signs between 2 and 4 h posttreatment (Table 1). Severe clinical signs were observed between 23 and 24 hours post treatment (Table 1). The main clinical signs observed during or immediately after exercise were tachycardia and dyspnea, reluctance to move, jugular engorgement (Figure 2A), and jugular pulsations. One animal exhibited more severe clinical signs as it remained recumbent for approximately 20 hours before it started to recover. Heart rates during exercise ranged from 96 to 160 beats per minute (bpm) while respiratory rates ranged from 24 to 56 breaths per minute from 4 to 24 hours post-treatment. Animals fully recovered from 44 to 84 hours post-treatment (Table 1).

Cattle that were dosed $20(n=2)$ and $30 \mathrm{~g} /$ $\mathrm{kg}(\mathrm{n}=1)$ exhibited mild clinical signs between $2 \mathrm{~h}$ and $4 \mathrm{~h}$ post-treatment while severe clinical signs were observed between 6 and 8 hours post-treatment. Heart rates ranged from 92 and $220 \mathrm{bpm}$ while respiratory rates ranged from 24 to 60 breaths per minute until the clinical outcome of death. All three animals died, two animals died at 6.75 and 7.5 hours post-treatment,

Ciência Rural, v.47, n.3, 2017. 
Table 1 - Experimental poisoning by Niedenzuella stannea leaves in cattle.

\begin{tabular}{|c|c|c|c|c|c|c|c|}
\hline Bovines & Breed & Weight (kg) & Dose $\left(\mathrm{g} \mathrm{kg}^{-1}\right)$ & $\begin{array}{l}\text { Onset of mild } \\
\text { clinical signs }^{\mathrm{a}}\end{array}$ & $\begin{array}{l}\text { Onset of severe } \\
\text { clinical signs }{ }^{b}\end{array}$ & Clinical evolution & Outc $^{*}$ ome $^{\mathrm{c}}$ \\
\hline 1 & Girolando & 250 & 15 & $2 \mathrm{~h}$ & $23 \mathrm{~h}$ & $44 \mathrm{~h}$ & $\mathrm{R}$ \\
\hline 2 & Girolando & 220 & 15 & $5.75 \mathrm{~h}$ & $24 \mathrm{~h}$ & $84 \mathrm{~h}$ & $\mathrm{R}$ \\
\hline 3 & Girolando & 200 & 20 & $2 \mathrm{~h}$ & $8 \mathrm{~h}$ & $29.75 \mathrm{~h}$ & $\mathrm{D}$ \\
\hline 4 & Nelore & 310 & 20 & $2 \mathrm{~h}$ & $6.5 \mathrm{~h}$ & $6.75 \mathrm{~h}$ & D \\
\hline 5 & Girolando & 200 & 30 & $3.75 \mathrm{~h}$ & $7.25 \mathrm{~h}$ & $7.5 \mathrm{~h}$ & D \\
\hline 6 & Nelore & 165 & $4 / 24$ days $^{d}$ & $\mathrm{Nd}^{\mathrm{e}}$ & $\mathrm{Nd}$ & & \\
\hline 7 & Nelore & 161 & 4/24days & $\mathrm{Nd}$ & $\mathrm{Nd}$ & & \\
\hline 8 & Girolando & 340 & Control & $\mathrm{Nd}$ & $\mathrm{Nd}$ & & \\
\hline
\end{tabular}

${ }^{\text {a } T a c h y c a r d i a, ~ d y s p n e a, ~ a p a t h y, ~ f r e q u e n t ~ u r i n a t i o n, ~ r e l u c t a n c e ~ t o ~ m o v e, ~ a n d ~ e n g o r g e d ~ j u g u l a r . ~}$

${ }^{\mathrm{b}}$ Falling, recumbence, pedaling movements, opisthotonous, cyanosis, vocalization and cardiopulmonary arrest.

${ }^{\mathrm{c}} \mathrm{R}=$ recovered; $\mathrm{D}=$ died.

${ }^{\mathrm{d}} 4 \mathrm{~g} \mathrm{~kg}^{-1}$ daily during 24 days.

${ }^{\mathrm{e}}$ Not detected.

while one animal dosed at $20 \mathrm{~g} \mathrm{~kg}^{-1}$ died at $29 \mathrm{~h} 45 \mathrm{~min}$ post treatment (Table 1).

Cattle that received a dose of $4 \mathrm{~g} \mathrm{~kg}^{-1}$ for 24 days showed no clinical signs, nor did the control animal. Heart rate or respiratory rates did not change in these animals. These results suggested that the toxic effects of the plant is not cumulative and that animals have to ingest a large amount of the plant in a short period of time to become intoxicated. This information may aid livestock producers prevent the poisoning with adequate management practices.

The lethal dose of $N$. stannea, $20 \mathrm{~g} \mathrm{~kg}^{1}$, is significantly higher than other MFA-containing plants of the Malpighiceae family. The lethal dose of other Malpighiaceae species belonging to genus Amorimia range from 0.625 to $10 \mathrm{~g} \mathrm{~kg}^{-1}$ (TOKARNIA \& DÖBEREINER, 1973; GAVA et al., 1998; BECKER et al., 2013), while the lethal dose of Palicourea spp. range from 0,6 to $2 \mathrm{~g} \mathrm{~kg}^{-1}$ (TOKARNIA \& DÖBEREINER, 1986). Although the lethal dose of $N$. stannea is an order of magnitude higher than Palicourea spp. and at least 2 times higher than Amorimia spp., $\boldsymbol{N}$. stannea caused numerous cases of poisonings in field conditions because the regrowth (sprouting) of the plant is coincident with periods of drought, when there is an other shortage forage. Onset of mild and severe clinical signs reported here are consistent with the experimental reproduction of poisoning with other MFA-containing

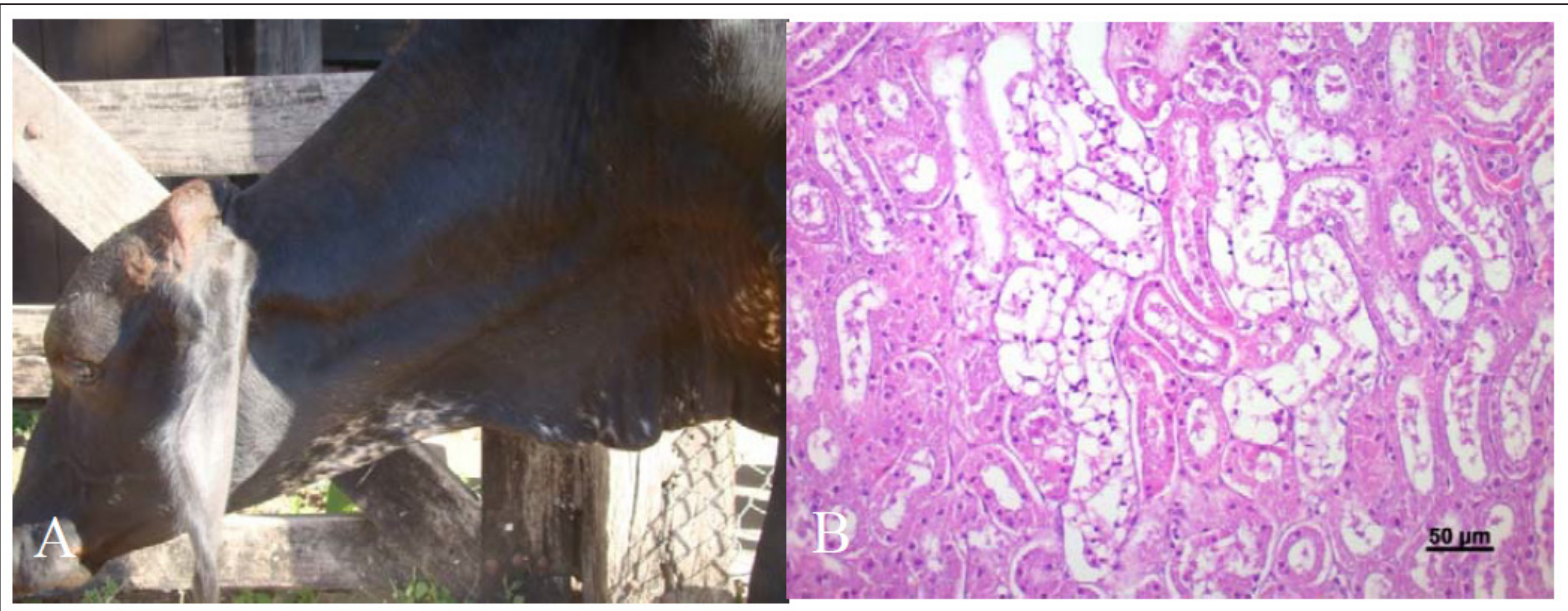

Figure 2 - Experimental intoxication by Niedenzuella stannea. A) Bovine 5 poisoned by Niedenzuella stannea showing engorgement of the jugular vein. B). Bovine 3, Kidney. Hidropic-vacuolar degeneration and picnosis are observed in the epithelial cells of the convoluted tubes. HE, Bar=50 $\mu \mathrm{m}$. 
plants. Generally there is a period of mild clinical signs followed by a second phase of more severe clinical signs that is precipitated by exercise (TOKARNIA et al., 2012). In the results reported here, the first phase of mild clinical signs lasted 3.5 to 19 hours. This phase was followed by a second phase of severe clinical signs precipitated by exercise, which lead to either gradual recovery or death. Two animals dosed at $15 \mathrm{~g} \mathrm{~kg}^{-1}$ recovered completely within 21 and 60 hours after the onset of severe clinical signs. One animal dosed at 20 and one at $30 \mathrm{~g} \mathrm{~kg}^{-1}$ died within 15 minutes of the onset of severe clinical signs while the other animal dosed at $20 \mathrm{~g} \mathrm{~kg}^{-1}$ died $21.75 \mathrm{~h}$ after the onset of severe clinical signs. The longer time of $21.75 \mathrm{~h}$ for clinical resolution in the one animal dosed at $20 \mathrm{~g} \mathrm{~kg}^{-1}$ has occasionally been observed in experimental poisoning of cattle by other plants that caused sudden death (TOKARNIA et al., 1994; HELAYEL et al., 2009).

All three animals that died showed similar gross lesions including engorgement of the large veins, severe lung edema, and petechiae, ecchymosis and suffusions in the pericardium, epicardium and pleura. Gross lesions reported here are observed in animals that die of acute cardiac failure (JONES et al., 1997), similar to cattle experimentally poisoned by MFA (NOGUEIRA et al., 2010), and are observed in poisonings by other MFA-containing plants (TOKARNIA \& DÖBEREINER 1986; TOKARNIA et al., 2012; BECKER et al., 2013). Lung congestion and edema varying from mild to severe were observed in two animals and hepatic congestions were observed in one animal. Additionally, in the animal that was dosed $20 \mathrm{~g} \mathrm{~kg}^{-1}$ and died at 29.75 hours post treatment, hydropic vacuolar degeneration and necrosis of epithelial cells of the kidney were observed (Figure 2B). This lesion is commonly reported in MFA poisoning (NOGUEIRA et al., 2010) and in the poisoning by MFA-containing plants (TOKARNIA et al., 2002; PAVARINI et al., 2011; DUARTE et. al., 2013). Although a non-specific lesion (PEIXOTO et al., 2011), as it was not reported in all animals poisoned (TOKARNIA \& DÖBEREINER, 1986), it is important diagnostic lesion in animals poisoned by MFA-containing plants. It is hypothesized that the period between the ingestion of the plant and death may be related with the occurrence of this specific lesion as it is more frequent in cases in which this period between ingestion and death is greater than 12 hours (TOKARNIA \& DÖBEREINER, 1986).

MFA was detected in $N$. stannea plant material. Monofluoracetate concentrations were highly variable between the different plant parts. The relative concentrations of MFA in different plant parts of $\boldsymbol{N}$. stannea are consistent with observations for other MFA containing plants (LEE et al., 2014). Concentrations were the greatest in seeds $(0.06 \%)$, followed by fruits $(0.0008$ to $0.02 \%)$, flowers $(0.0003$ to $0.006 \%)$, and immature leaves/sprouts $(0.0003 \%)$. MFA was not detected in mature leaves. This is the first report that $N$. stannea contains MFA.

\section{CONCLUSION}

Niedenzuela stannea contains MFA and causes acute cardiac failure in cattle of farms close to the Araguaia river and its tributaries in the eastern region of the state of Mato Grosso. Clinical signs and pathology observed in the cattle poisoned experimentally with $N$. stannea are consistent with those observed in poisoned animals by other MFA-containing plants. This study suggested that $\boldsymbol{N}$. stannea is likely responsible for livestock deaths in other Brazilian States and other countries where the plant occurs.

\section{ACKNOWLEDGEMENTS}

The authors acknowledge Dr. William R. Anderson (University of Michigan Herbarium, Ann Arbor, Michigan, EUA) for the taxonomic identification of the plants. This project was financially supported by Fundação de Amparo à Pesquisa do Estado de Mato Grosso (FAPEMAT-Proc. n. 156883/2014) and National Institute of Science and Technology for the Control of Plant Poisonings (Proc. n. 573534/2008-0)

\section{BIOETHICS AND BIOSSECURITY COMMITTEE APPROVAL}

All animal research was performed in accordance with the principles recommended by the Sociedade Brasileira de Ciência de Animais de Laboratório (SBCAL) and was approved by the Ethical Committee in the Use of Experimental Animals of the Universidade Federal de Mato Grosso (CEUA-UFMT) (protocol N. 23108016273/13-0).

\section{REFERENCES}

ANDERSON, W. R. Eight Segregates from the Neotropical Genus Mascagnia (Malpighiaceae). Novon AJ Bot Nomencl, v.16, p.168-204, 2006. Available from: <http://www.bioone.org/doi/abs/10.3417/1055317 7(2006)16\%5B168:ESFTNG\%5D2.0.CO\%3B2>. Accessed: Aug. 01, 2016. doi: 10.3417/1055-3177(2006)16[168:ESFTNG]2.0.CO;2.

BARBOSA, J. D. et al. Comparison of the sensibility of cattle and buffaloes to poisoning by Palicourea marcgravii (Rubiaceae). Pesq Vet Bras, v.23, n.4, p.167-172, 2003. Available from: <http:// www.scielo.br/pdf $/ \% 0 \mathrm{D} / \mathrm{pvb} / \mathrm{v} 23 \mathrm{n} 4 / 18732 . \mathrm{pdf}>$. Accessed: Jan. 02, 2016. doi: 10.1590/S0100-736X2003000400005.

BECKER, M. et al. The importance of poisoning by Amorimia pubiflora (Malpighiaceae) in cattle in Mato Grosso: experimental reproduction of the poisoning in sheep and cattle. Pesq Vet Bras, v.33, p.1049-1056, 2013. Available from: <http:// www.scielo.br/scielo.php?script $=$ sci_arttext\&pid $=$ S0 10073 
6X2013000900001>. Accessed: Aug. 05, 2016. doi: 10.1590/ S0100-736X2013000900001.

CALDEIRA, F. H. B. et al. Sudden death associated to Niedenzuella stannea (Malpiguiaceae) in cattle in the State of Mato Grosso, Brazil: Importance and epidemiological aspects. Pesq Vet Bras, (in press).

CARVALHO, F. K. L. et al. Determination of toxicity in rabbits and corresponding detection of monofluoroacetate in four Palicourea (Rubiaceae) species from the Amazonas state, Brazil. Toxicon, v.109, p.42-44, 2016. Available from: <http://www.sciencedirect. com/science/article/pii/S0041010115301355>. Accessed: Aug. 10, 2016. doi: 10.1016/j.toxicon.2015.11.009.

CLARKE D. D. Fluoroacetate and fluorocitrate: Mechanism of action. Neurochem Res, v.16, n.9, p.1055-1058, 1991.

DUARTE, A. L. et al. Poisoning by Amorimia spp. in ruminants. Ciênc Rural, v.43, n.7, p.1294-1301, 2013. Available from: $<$ http://www.scielo.br/scielo.php?script=sci_arttext\&pid $=$ S0103-84782013000700024 $>$. Accessed: June 12, 2016. doi: 10.1590/S0103-84782013005000081.

GAVA, A. et al. Sudden death in cattle by Mascagnia spp. (Malpighiaceae) in the State of Santa Catarina, Brazil. Pesq Vet Bras, v.18, n.1, p.16-20, 1998. Available from: <http://www.scielo.br/scielo. php?pid=S0100-736X1998000100003\&script $=$ sci_abstract\&tlng $=$ pt $>$. Accessed: Feb. 07, 2016. doi: 10.1590/S0100-736X̄1998000100003.

JONES, T. C. et al. The cardiovascular system. In: Veterinary pathology. 6. ed. Pennsylvania: Williams \& Wilkins, 1997. p.975-1008.

LEE, S. T. et al. Monofluoroacetate-containing plants that are potentially toxic to livestock. J Agric Food Chem, v.62, p.73457354, 2014. Available from: <http://pubs.acs.org/doi/abs/10.1021/ jf500563h>. Accessed: June 10, 2016. doi: 10.1021/jf500563h.

LEE, S. T. et al. Detection of monofluoroacetate in Palicourea and Amorimia species. Toxicon, v.60,p.791-796,2012.Available from: $<$ http:// www.sciencedirect.com/science/article/pii/S0041010112005065>. Accessed: Aug. 10, 2016. doi: 10.1016/j.toxicon.2012.05.029.

LUNA, L. G. et al. Manual of histologic staining methods of the Armed Forces Institute of Pathology. 3. ed. Nova York: McGraw Hill, 1968. 258p.

MAMEDE, M. C. H. Niedenzuella in lista de espécies da flora do Brasil. Jardim Botânico do Rio de Janeiro, 2010. Available from: $<$ http:// floradobrasil.jbrj.gov.br/2010/FB101449>. Accessed: Apr. 10, 2015.
NOGUEIRA, V. A. et al. Experimental poisoning by sodium monofluoroacetate in cattle: clinical and pathological aspects. Pesq Vet Bras, v.30, p.533-540, 2010. Available from: <http:// www.scielo.br/scielo.php? script $=$ sci arttext\&pid $=\mathrm{S} 0100$ 736X2010000700004>. Accessed: June 10, 2016. doi: 10.1590/ S0100-736X2010000700004.

PEIXOTO, P. V. et al. Relationship between a peculiar form of hydropic-vacuolar degeneration of the distal convoluted tubules, monofluoroacetate poisoning, and plants that cause "sudden death" in Brazil. In: RIET-CORREA et al. Poisoning by plants, mycotoxins, and related toxins. London: CABI, 2011. p.365-372. doi: $10.1079 / 9781845938338.0365$.

PAVARINI, S. P. et al. Sudden death in cattle due to the consumption of Amorimia exotropica (Malpighiaceae) in Rio Grande do Sul, Brazil. Pesq Vet Bras, v.31, p.291-296, 2011. Available from: $<$ http://www.scielo.br/scielo.php?script=sci_arttext\&pid=S0100736X2011000400004>. Accessed: June 09, 2016. doi: 10.1590/ S0100-736X2011000400004.

TOKARNIA, C. H. et al. Comparative epidemiological, clinical and pathological aspects of poisoning by Arrabidaea bilabiata (Bignoniaceae) in buffalo and cattle. Pesq Vet Bras, v.24, n.2, p.74-79, 2004. Available from: <http:// www.scielo.br/scielo.php? script $=\mathrm{sci}$ arttext\&pid $=\mathrm{S} 0100$ 736X2004000200005>. Accessed: June 05, 2016. doi: 10.1590/ S0100-736X2004000200005.

TOKARNIA, C. H. et al. Plantas tóxicas do Brasil para animais de produção. 2.ed. Rio de Janeiro: Helianthus, 2012. 566p.

TOKARNIA, C. H.; DÖBEREINER, J. Intoxicação por Mascagnia pubiflora em bovinos no Estado de Mato Grosso. Pesq Agropec Bras, v.8, p.61-68, 1973. Available from: <https://seer. sct.embrapa.br/index.php/pab/article/view/17373>. Accessed June $05,2016$.

TOKARNIA, C. H.; DÖBEREINER, J. Intoxicação por Palicourea marcgravii (Rubiaceae) em bovinos no Brasil. Pesq Vet Bras, v.6, n.3, p.73-92, 1986.

TOKARNIA, C. H. et al. Intoxicação por Mascagnia aff. rigida (Malpighiaceae) em bovinos no norte do Espirito Santo. Pesq Vet Bras, v.5, n.3, p.77-91, 1985.

TOKARNIA, C. H. et al. Poisonous plants affecting livestock in Brazil. Toxicon, v,40, p.1635-1660, 2002. Avaliable from: $<$ http:// www.sciencedirect.com/science/article/pii/S0041010102002398>. Accessed: Feb.10, 2016. doi: 10.1016/S0041-0101(02)00239-8. 